\title{
Unusual Seven Coordination of Oxovanadium(V) Oximato Complex: Synthesis and X-Ray Crystal Structure
}

\author{
Shadia A. Elsayed, Ahmed M. El-Hendawy, and Mohamed I. El-Mahdy \\ Chemistry Department, Faculty of Science, Damietta University, New Damietta 34517, Egypt \\ Correspondence should be addressed to Ahmed M. El-Hendawy; amelhendawy@yahoo.com
}

Received 3 November 2013; Accepted 1 December 2013; Published 4 March 2014

Academic Editors: K. Y. Choi, R. Meijboom, and S. Turmanova

Copyright ( 2014 Shadia A. Elsayed et al. This is an open access article distributed under the Creative Commons Attribution License, which permits unrestricted use, distribution, and reproduction in any medium, provided the original work is properly cited.

The new oxovanadium $(\mathrm{V})$ complex, $\left[\mathrm{VO}(\mathrm{acac})(\right.$ dametsc) $]$ (1) $\left(\mathrm{acac}=\right.$ acetylacetonate $(-1), \mathrm{H}_{2}$ dametsc $=$ diacetylmonoxime-4ethylthiosemicarbazone), has been prepared and characterized by studying its physicochemical properties. The X-ray crystal structure of the complex (1) has been determined and showed the presence of vanadium $(\mathrm{V})$ atom in a unique heptacoordination state with distorted pentagonal bipyramidal geometry. The oximato ligand in the pentagonal plane is bonded to the central vanadium atom in dihapto $\left(\eta^{2}=\mathrm{N}, \mathrm{O}\right)$ manner with the formation of three membered ring, while the other three coordination sites in the plane are occupied by hydrazinic imine nitrogen, thiolate sulfur, and one of the acac oxygen atoms. The axial position sites are defined by the other acac oxygen and the trans oxo-atom. The supramolecular structure of the complex is exclusively constructed by intermolecular interactions, $\mathrm{N}-\mathrm{H} \cdots \mathrm{O}$ and $\mathrm{C}-\mathrm{H} \cdots \mathrm{O}$.

"This paper is dedicated to Professor William (Bill) P. Griffith, Imperial College, London, for his many contributions in coordination chemistry and their X-ray crystal structure determinations."

\section{Introduction}

Although heptacoordinate pentagonal bipyramidal vanadium compounds are still rare with conventional ligands, peroxo $\left(\eta^{2}-\mathrm{O}, \mathrm{O}\right)$ and oximato $\left(\eta^{2}-\mathrm{O}, \mathrm{N}\right)$ vanadium $(\mathrm{V})$ complexes usually adopt this structure [1,2]. Iron(III) and nickel(II) complexes of meridional bis-diacetylmonoxime Schiff base of S-methyl/S-benzyldithiocarbazate $\left(\mathrm{H}_{2}\right.$ damsm $/ \mathrm{H}_{2}$ damsb), $\left[\mathrm{Fe}(\mathrm{Hdamsm})_{2}\right]^{+}(\mathbf{2})$, and $\left[\mathrm{Ni}(\mathrm{Hdamsb})_{2}\right](3)$, each complex had a distorted octahedral geometry in which the ligand behaves as a monoanionic NNS-tridentate and coordinates via oxime nitrogen, hydrazinic imine nitrogen, and thiolate sulfur with silent hydroxo oxime group $[3,4]$. There is interest in the coordination chemistry of oximes as they have served as models for biological systems such as vitamin B12 and myocardial perfusion imaging agents [5]. Oxovanadium(V) complexes associated with one acetylacetonato group have not been isolated so far, though their effectiveness as active intermediate in peroxide oxidation of thioether to sulfoxide [6]. We report here the synthesis and X-ray crystal structure of the new oxovanadium(V) complex (1) in its unusual heptacoordination geometry containing both acetylacetonato and oximato ligands.

\section{Experimental}

2.1. Synthesis. The ligand of diacetylmonoxime-4-ethylthiosemicarbazone $\left(\mathrm{H}_{2}\right.$ dametsc $)$ is prepared by using a similar method to that previously reported in [3]. To a solution of $\mathrm{H}_{2}$ dametsc $(0.108 \mathrm{~g}, 0.5 \mathrm{mmol})$ in hot methanol $\left(12 \mathrm{~cm}^{3}\right)$, [VO (acac $)_{2}$ ] [7] $(0.133 \mathrm{~g}, 0.5 \mathrm{mmol})$ was added. The mixture was then stirred and refluxed on steam bath for $1 \mathrm{~h}$; reddish brown solution was obtained and left for slow evaporation at room temperature. Red crystals so formed were suitable for X-ray diffraction; they were filtrated off, washed carefully with little by methanol, followed by ether, and dried in vacuo. Yield, $0.13 \mathrm{~g}$ (70\%); Anal. Calc. for $\mathrm{C}_{12} \mathrm{H}_{19} \mathrm{~N}_{4} \mathrm{O}_{4} \mathrm{SV}$ : C, 39.3; H, 5.2; N, 15.3\%. Found: C, 39.1; H, 5.1; N, $15.2 \%$. IR ( $\mathrm{KBr}$ disc): $3241 \mathrm{~m}[\nu(\mathrm{N}-\mathrm{H})] ; 1566 \nu \mathrm{s}, 1379 \mathrm{~s}[\nu(\mathrm{C}=\mathrm{O})$, 
acac]; 943 vs $[\nu(\mathrm{V}=\mathrm{O})]$. UV-Vis. $\left(\mathrm{CH}_{2} \mathrm{Cl}_{2}\right) ; \lambda_{\max } 325 \mathrm{~nm}$ $\left(\varepsilon, 11350 \mathrm{M}^{-1} \mathrm{~cm}^{-1}\right)$. Molar conductivity $\left(\Omega^{-1} \mathrm{~cm}^{2} \mathrm{~mol}^{-1}\right), 6$ $(\mathrm{MeOH}) ; \mu_{\mathrm{eff}}=0 \mathrm{BM}$.

2.2. X-Ray Crystallographic Study. Red monoclinic crystals of $[\mathrm{VO}(\mathrm{acac})($ dametsc)] (1) having appropriate dimensions were measured on Bruker Kappa CCD diffract meter equipped with graphite-monochromated $\mathrm{MoK} \alpha$ radiation $(\lambda=0.71073 \AA)$; the unit cell dimensions and intensity data were measured at $298 \mathrm{~K}$. The crystal data were collected up to $54.97^{\circ}$ in $2 \theta$ and the structure was solved by least squares fit of the angular setting of strong reflection based on $F^{2}$. The program used to solve structure was SIR92 [8], while the program used to refine structure was maXus [9]. Integration and scaling of the reflections were performed with the HKL Denzo-Scalepack system of programs [10]. The nonhydrogen atoms were refined with anisotropic thermal parameters. Crystallographic data for (1) are summarized in Table 1.

CCDC795958 contains the supplementary crystallographic data for the paper. These data can be obtained free of charge from the Cambridge Crystallographic Data Centre.

\section{Results and Discussion}

Our oxovanadium(V) complex (1) was prepared under aerobic conditions in $\mathrm{MeOH}$, by exchange of one acac in $\left[\mathrm{V}^{\mathrm{IV}} \mathrm{O}(\mathrm{acac})_{2}\right]$ with the tetradentate ligand in its di-deprotonated form (dametsc ${ }^{2-}$ ). A perspective view of the complex (1) is illustrated in Figure 1. As indicated by the bond angles in Table 2, the vanadium atom has the pentagonal bipyramid geometry. In particular, the sum of angles of the pentagonal plane $\left(\sim 357.4^{\circ}\right)$, which is bite less than the ideal value of $360^{\circ}$, the axial, $\mathrm{O} 7-\mathrm{V}-\mathrm{O} 3$ has the angle $177.37(8)^{\circ}$ (near $180^{\circ}$ ), similarly typical to that found for $\left[\mathrm{V}^{\mathrm{III}}(\right.$ teg $\left.)(\mathrm{Br})_{2}\right] \mathrm{Br}$ (teg = pentadentate tetraglyme ligand, $\left.\mathrm{CH}_{3} \mathrm{O}\left(\mathrm{CH}_{2} \mathrm{CH}_{2} \mathrm{O}\right)_{4} \mathrm{CH}_{3}\right)$ [11]. The axial V=O7 [1.586 (2) $\AA$ ] is arranged symmetrically above the approximate pentagonal plane in which two $\mathrm{V}-$ O6,8 bonds, two V-N4,9 bonds, and one V-S2 bond all make angles ranging from $94.52(9)^{\circ}$ to $98.82(9)^{\circ}$. The oximato ligand is bonded in a dihapto $\left(\eta^{2}-\mathrm{N}, \mathrm{O}\right)$ manner with the formation of a three membered ring that has an angle, O8$\mathrm{V}-\mathrm{N} 9$ equal to $37.28(8)^{\circ}$, similar to those found for other $\eta^{2}$ NO-oximato vanadium(V) complexes [2].

The longer bond length C11-S2 [1.721 (3) $\AA]$ is close to that found for similar related complexes (2) and (3) which had N,N,S-donor ligands chelated in their thiolate form, in contrast to the shorter lengths for the $\mathrm{C}=\mathrm{S}(\sim 1.68 \AA)$ double bond (thione form) found in the free ligand and its nickel(II) complex $\left[\mathrm{Ni}\left(\mathrm{H}_{2}\right.\right.$ damtsc $\left.)\right] \mathrm{Cl}_{2}$ [12]. This thiol form is also identified by the fact that the hydrazinic nitrogen N4 is not bonded to any hydrogen atom and has the distance, C11-N4 [1.338 (3) $\AA]$, that is in the range for $\mathrm{C}=\mathrm{N}(\sim 1.30 \AA)$ double bond [13]. Similar bond lengths for N4-N5 [1.367 (3) A] were observed for the complexes (2) and (3) $[3,4]$.

The trans-influence of oximato oxygen (O8) and oxo ligand $(\mathrm{O} 7)$ on $\mathrm{S} 2$ and $\mathrm{O} 3$ atoms, respectively, manifests itself in elongation of V-S2 [2.4899 (9) A]], compared to a short bond length in related $\mathrm{N}, \mathrm{N}, \mathrm{S}$-thiolato oxime metal
TABLE 1: Crystal data and structure refinement parameters for $[\mathrm{VO}(\mathrm{acac})($ dametsc $)](\mathbf{1})$.

\begin{tabular}{|c|c|}
\hline $\mathrm{C}_{12} \mathrm{H}_{19} \mathrm{~N}_{4} \mathrm{O}_{4} \mathrm{SV}$ & Empirical formula \\
\hline 366.314 & Formula weight \\
\hline $298 \mathrm{~K}$ & Temperature \\
\hline 0.71073 & Wavelength \\
\hline Monoclinic & Crystal system \\
\hline \multirow[t]{2}{*}{$P 2_{1} / c$} & Space group \\
\hline & Unit cell dimensions \\
\hline $14.7658(6) \AA$ & $a$ \\
\hline $8.5776(3) \AA$ & $b$ \\
\hline $13.4142(5) \AA$ & $c$ \\
\hline $90.00^{\circ}$ & $\alpha=\gamma$ \\
\hline $95.2289(13)^{\circ}$ & $\beta$ \\
\hline $1691.91(11) \AA^{3}$ & Volume \\
\hline 4 & $Z$ \\
\hline $1.438 \mathrm{mg} \cdot \mathrm{m}^{-3}$ & Density \\
\hline $0.73 \mathrm{~mm}^{-1}$ & Absorption coefficient \\
\hline $2.910-27.485^{\circ}$ & Theta range for data collection \\
\hline $\begin{array}{l}-19 \leq h \leq 19 \\
-10 \leq k \leq 11,-17 \leq l \leq 17\end{array}$ & Index ranges \\
\hline 4455 & Independent reflections \\
\hline 1729 & Observed reflections \\
\hline None & Absorption correction \\
\hline 1727 & Reflections collected $[I>3 \sigma(I)]$ \\
\hline $\begin{array}{l}\text { Full-matrix least squares on } \\
F^{2}\end{array}$ & Refinement method \\
\hline $4455 / 0 / 199$ & Reflections/restraints/parameters \\
\hline $0.76,-0.81$ & $\Delta \rho_{\max }, \Delta \rho_{\min }\left(\mathrm{e} \AA^{-3}\right)$ \\
\hline$R_{1}=0.050, w R_{2}=0.094$ & Final $R$ indices \\
\hline$R_{1}=0.142, w R_{2}=0.116$ & $R$ indices (all data) \\
\hline
\end{tabular}

TABLE 2: Selected bond distances $(\AA)$ and angles (deg) for $[\mathrm{VO}(\mathrm{acac})($ dametsc)] (1).

\begin{tabular}{lccc}
\hline V1-S2 & $2.4899(9)$ & O7-V1-O3 & $177.37(8)$ \\
V1-N4 & $2.025(2)$ & S2-V1-N4 & $66.44(6)$ \\
V1-N9 & $1.909(3)$ & N4-V1-N9 & $76.43(9)$ \\
V1-O8 & $2.105(2)$ & N9-V1-O8 & $37.28(8)$ \\
V1-O6 & $1.964(2)$ & O8-V1-O6 & $90.82(9)$ \\
V1-O3 & $2.159(2)$ & O6-V1-S2 & $86.42(7)$ \\
V1-O7 & $1.586(2)$ & O7-V1-O6 & $94.52(9)$ \\
N4-N5 & $1.367(3)$ & O7-V1-O8 & $96.59(9)$ \\
C11-N4 & $1.338(3)$ & O7-V1-N9 & $97.64(10)$ \\
C11-S2 & $1.721(3)$ & O7-V1-N4 & $98.82(9)$ \\
C12-N (5) & $1.300(3)$ & O7-V1-S2 & $95.20(8)$ \\
C13-N (9) & $1.292(4)$ & & \\
\hline
\end{tabular}

complexes (2) and (3) $[\mathrm{M}-\mathrm{S}, \sim 2.22-2.30 \AA]$, and also the distance V-O3 [2.159 (2) $\AA$ ] is longer than V-O6 [1.964 (2) $\AA$ ] for the chelated $\mathrm{O} 3, \mathrm{O} 6$ (in acac ligand) to vanadium atom. 
TABLE 3: Intermolecular hydrogen bonds $(\AA)$ and angles $\left({ }^{\circ}\right)$ in structure (1).

\begin{tabular}{llccc}
\hline $\mathrm{D}-\mathrm{H} \cdots \mathrm{A}$ & $\mathrm{D}-\mathrm{H}(\AA)$ & $\mathrm{H} \cdots \mathrm{A}(\AA)$ & $\mathrm{D} \cdots \mathrm{A}(\AA)$ & $\mathrm{D}-\mathrm{H} \cdots \mathrm{A}\left({ }^{\circ}\right)$ \\
\hline $\mathrm{N} 10-\mathrm{H} 10 \cdots \mathrm{O}^{\mathrm{i}}$ & $0.960(2)$ & 2.040 & 2.935 & $154.35(14)$ \\
$\mathrm{C} 22-\mathrm{H} 22 \mathrm{~B} \cdots \mathrm{O}^{\mathrm{i}}$ & $0.960(5)$ & $2.676(2)^{\mathrm{ii}}$ & 3.616 & 166.17 \\
\hline
\end{tabular}

Symmetry codes: ${ }^{\mathrm{i}} x, 1 / 2-y, z-1 / 2 ;{ }^{\mathrm{ii}} x, 1 / 2-y, 1 / 2+z$.

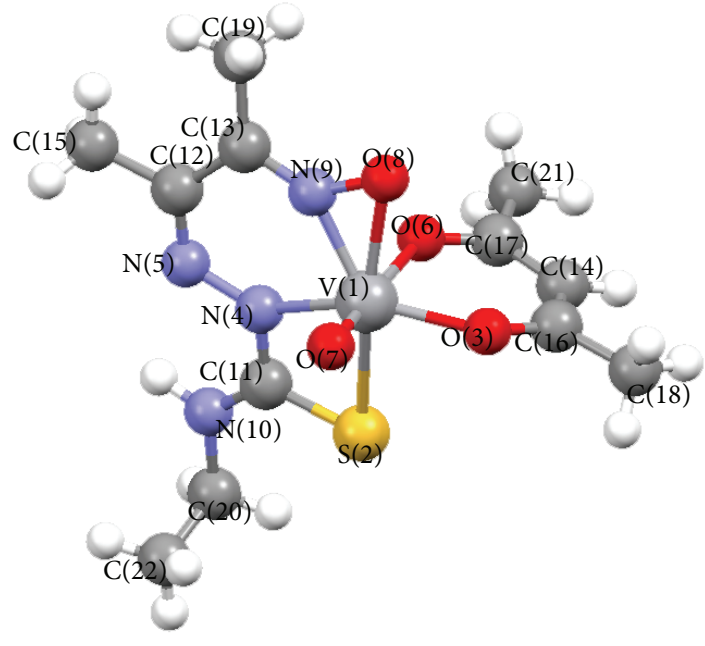

Figure 1: Molecular structure of the complex [VO(acac)(dametsc)] (1).

In structure 1, the coordinated heteroligands, acac ${ }^{-}$ and dametsc ${ }^{2-}$, are both anionic; however, they differ in the charge. The doubly charged ligand is preferentially bound to vanadium atom in the equatorial plane, while the monocharged bidentate ligand is chelated in both the equatorial and axial positions. This is similarly observed for $\mathrm{O}, \mathrm{O}$ and $\mathrm{N}, \mathrm{O}$-bidentate peroxo $\left(\mathrm{O}_{2}{ }^{2-}\right)$ oxalate $\left(\mathrm{ox}^{2-}\right)$ and picolinato $\left(\mathrm{pic}^{-}\right)$ligands in the pentagonal bipyramid complex, $\left[\mathrm{V}^{\mathrm{V}} \mathrm{O}\left(\mathrm{O}_{2}\right)(\mathrm{pic})(\mathrm{ox})\right][14]$.

Figure 2 shows the intermolecular hydrogen bonding (for $\mathrm{H}$... O interactions) characterized in the lattice for complex (1). Each pair of (1) molecules is interconnected via hydrogen bonds; oxo ligand (O7) and oxygen atom (O6) of acac ligand from one molecule are attached with the other neighboring molecule through hydrogen atoms in N10-H10 and C22$\mathrm{H} 22 \mathrm{~B}$, respectively. Strong interaction has been found for $\mathrm{N} 10-\mathrm{H} 10 \cdots \mathrm{O} 7\left[\mathrm{~d}_{\mathrm{H}}(\mathrm{H} 10 \cdots \mathrm{O} 7)=2.040 \AA\right]$ compared to C22H22B $\cdots$ O6 $\left[\mathrm{d}_{\mathrm{H}}(\mathrm{H} 22 \mathrm{~B} \cdots \mathrm{O} 6)=2.676(2) \AA\right]$ (Table 3). However, the latter $\mathrm{C}-\mathrm{H}$... O interaction is somewhat scarce in coordination compounds; it has been recognized to play an important role in protein structure and stability [15]. The theoretical calculations showed that the $\mathrm{C}-\mathrm{H} \cdots \mathrm{O}$ association energy, $-2.1 \mathrm{kcal} \cdot \mathrm{mol}^{-1}$, essentially contributes to the structure stabilization [16].

\section{Conclusion}

The ligand, diacetylmonoxime-4-ethylthiosemicarbazone $\left(\mathrm{H}_{2}\right.$ dametsc $)$, reacts with $\left[\mathrm{VO}(\mathrm{acac})_{2}\right]$ in aerobic conditions

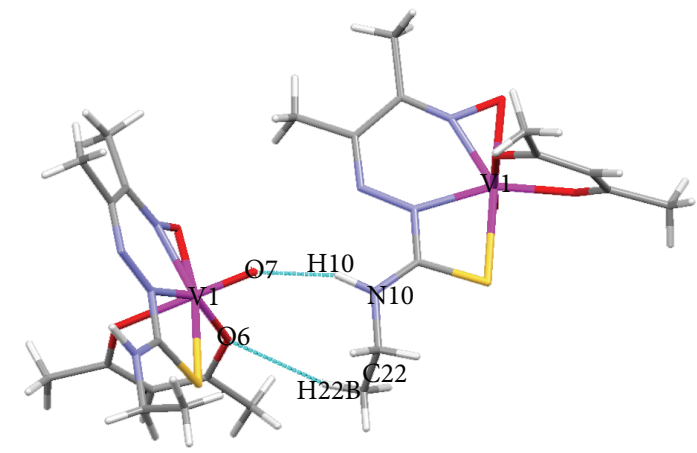

FIGURE 2: Hydrogen bonding interactions $(\mathrm{H} \cdots \mathrm{O})$ in the lattice of $[\mathrm{VO}(\mathrm{acac})($ dametsc)] (1).

to form the new oxovanadium(V) complex, [VO(acac) (dametsc)]. The X-ray crystal structure of the complex has been determined and shows that it has a distorted pentagonal bipyramid geometry. The intermolecular interactions, N$\mathrm{H} \cdots \mathrm{O}$ and $\mathrm{C}-\mathrm{H} \cdots \mathrm{O}$, stabilize the supramolecular structure of the complex.

\section{Conflict of Interests}

The authors declare that they do not have conflict of interests regarding the publication of this paper.

\section{Acknowledgments}

The authors thank National Research Centre in Cairo for the $\mathrm{X}$-ray crystallographic facility.

\section{References}

[1] H. Michibata, Vanadium and Molecular Biological Approaches, Springer, Amsterdam, The Netherlands, 2012.

[2] V. Sharma, V. Sharma, R. Bohra, J. E. Drake, M. B. Hursthouse, and M. E. Light, "Synthesis and characterization of some oxovanadium(V) complexes with internally functionalized oximes: crystal and molecular structures of heptacoordinated [VOON $\left.=\mathrm{C}\left(\mathrm{CH}_{3}\right)\left(\mathrm{C}_{4} \mathrm{H}_{3} \mathrm{O}^{-2}\right) 3\right]$ and $\left[\mathrm{VO}=\mathrm{C}\left(\mathrm{CH}_{3}\right)\left(\mathrm{C}_{4} \mathrm{H}_{3} \mathrm{~S}^{-2}\right) 3\right.$ ] $0.5 \mathrm{C}_{6} \mathrm{H}_{6}$," Inorganica Chimica Acta, vol. 360 , no. 6, pp. 20092015, 2007.

[3] A. M. El-Hendawy, A. M. Fayed, and M. R. Mostafa, "Complexes of a diacetylmonoxime Schiff base of $S$-methyldithiocarbazate $\left(\mathrm{H}_{2}\right.$ damsm) with $\mathrm{Fe}(\mathrm{III}), \mathrm{Ru}(\mathrm{III}) / \mathrm{Ru}(\mathrm{II})$, and $\mathrm{V}(\mathrm{IV})$; Catalytic activity and X-ray crystal structure of $\left[\mathrm{Fe}(\mathrm{Hdamsm})_{2}\right] \mathrm{NO}_{2} \cdot \mathrm{H}_{2} \mathrm{O}$," Transition Metal Chemistry, vol. 36, no. 4, pp. 351-361, 2011. 
[4] N. M. H. Salem, L. El-Sayed, and M. F. Iskander, "Metal complexes derived from hydrazoneoxime ligands: IV. Molecular and supramolecular structures of some nickel(II) complexes derived from diacetylmonoxime S-benzyldithiocarbazonate," Polyhedron, vol. 27, no. 15, pp. 3215-3226, 2008.

[5] W. A. Wolkert and T. J. Hoffman, "Therapeutic radiopharmaceuticals," Chemical Reviews, vol. 99, pp. 2269-2292, 1999.

[6] H. Schmidt, M. Bashirpoor, and D. Rehder, "Structural characterization of possible intermediates in vanadium-catalysed sulfide oxidation," Journal of the Chemical Society, no. 19, pp. 3865-3870, 1996.

[7] R. A. Rowe and M. M. Jones, "Preparation from vanadium(V) oxide through prior reduction to oxovanadium(IV) ion," Inorganic Synthesis, vol. 5, p. 114, 1957.

[8] A. Altomare, G. Cascarano, C. Giacovazzo et al., "SIR92: a program for automatic solution of crystal structures by direct methods," Journal of Applied Crystallography, vol. 27, p. 435, 1994.

[9] S. Mackay, C. Gilmore, C. J. Edwards, N. S. tewart, and K. Shankland, MasXus Computer Program for the Solution and Refinement of Crystal Structures Bruker Nonius, 1999.

[10] Z. Otwinowski and W. Minor, "Processing of X-ray diffraction data collected in oscillation mode," in Methods in Enzymology, C. W. Carter Jr. and R. M. S. weet, Eds., vol. 276, p. 307, Academic Press, New York, NY, USA, 1997.

[11] R. Neumann and I. Assael, "Vanadium(V)/vanadium(III) redox couple in acidic organic media. Structure of a vanadium(III)tetraethylene glycol pentagonal-bipyramidal complex ([V(teg) $\left.\left.(\mathrm{Br})_{2}\right]^{+} \mathrm{Br}^{-}\right)$," Journal of the American Chemical Society, vol. 111, no. 22, pp. 8410-8413, 1989.

[12] K.-Y. Choi, S.-M. Yang, K.-C. Lee et al., "Synthesis, properties, and crystal structures of mononuclear nickel(II) and copper(II) complexes with 2-oximino-3-thiosemicarbazone-2,3butanedione," Transition Metal Chemistry, vol. 33, no. 1, pp. 99105, 2008.

[13] E. W. Yemeli Tido, G. O. R. Alberda van Ekenstein, A. Meetsma, and P. J. van Koningsbruggen, "Study of neutral Fe(III) complexes of pyridoxal-N-substituted thiosemicarbazone with desolvation-induced spin-state transformation above room temperature," Inorganic Chemistry, vol. 47, no. 1, pp. 143-153, 2008.

[14] J. Tatiersky, P. Schwendt, M. Sivák, and J. Marek, "Racemic monoperoxovanadium(v) complexes with achiral $\mathrm{OO}$ and on donor set heteroligands: synthesis, crystal structure and stereochemistry of $\left[\mathrm{NH}_{3}\left(\mathrm{CH}_{2}\right)_{2} \mathrm{NH}_{3}\right]\left[\mathrm{VO}\left(\mathrm{O}_{2}\right)(\mathrm{ox})(\mathrm{pic})\right] \cdot 2 \mathrm{H}_{2} \mathrm{O}$ and $\left[\mathrm{NH}_{3}\left(\mathrm{CH}_{2}\right)_{2} \mathrm{NH}_{3}\right]\left[\mathrm{VO}\left(\mathrm{O}_{2}\right)(\mathrm{ox})(\mathrm{pca})\right]$," Dalton Transactions, no. 13, pp. 2305-2311, 2005.

[15] G. Desiraju and T. Steiner, The Weak Hydrogen Bond in Structural Chemistry and Biology, Oxford University Press, Oxford, UK, 1999.

[16] R. Vargas, J. Garza, D. A. Dixon, and B. P. Hay, "How strong is the $\mathrm{C} \alpha-\mathrm{H}$... OC hydrogen bond?" Journal of the American Chemical Society, vol. 122, pp. 4750-4755, 2000. 

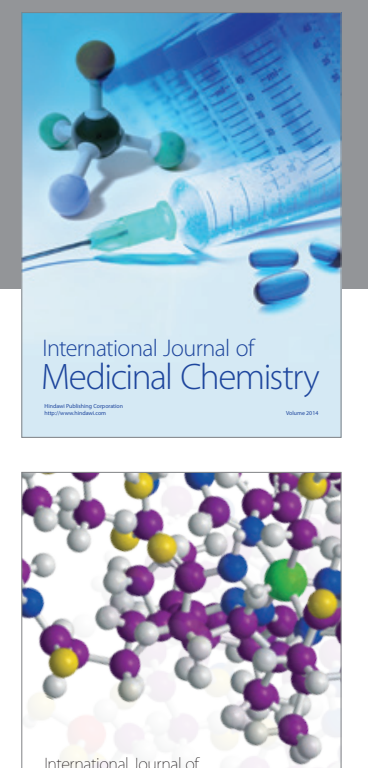

\section{Carbohydrate} Chemistry

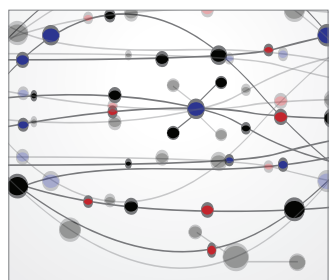

The Scientific World Journal
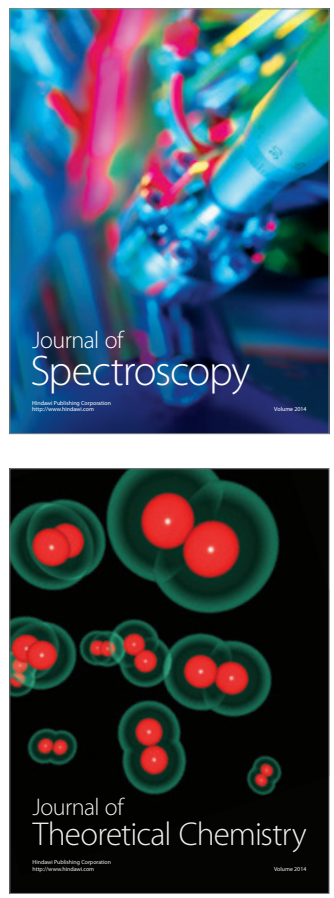
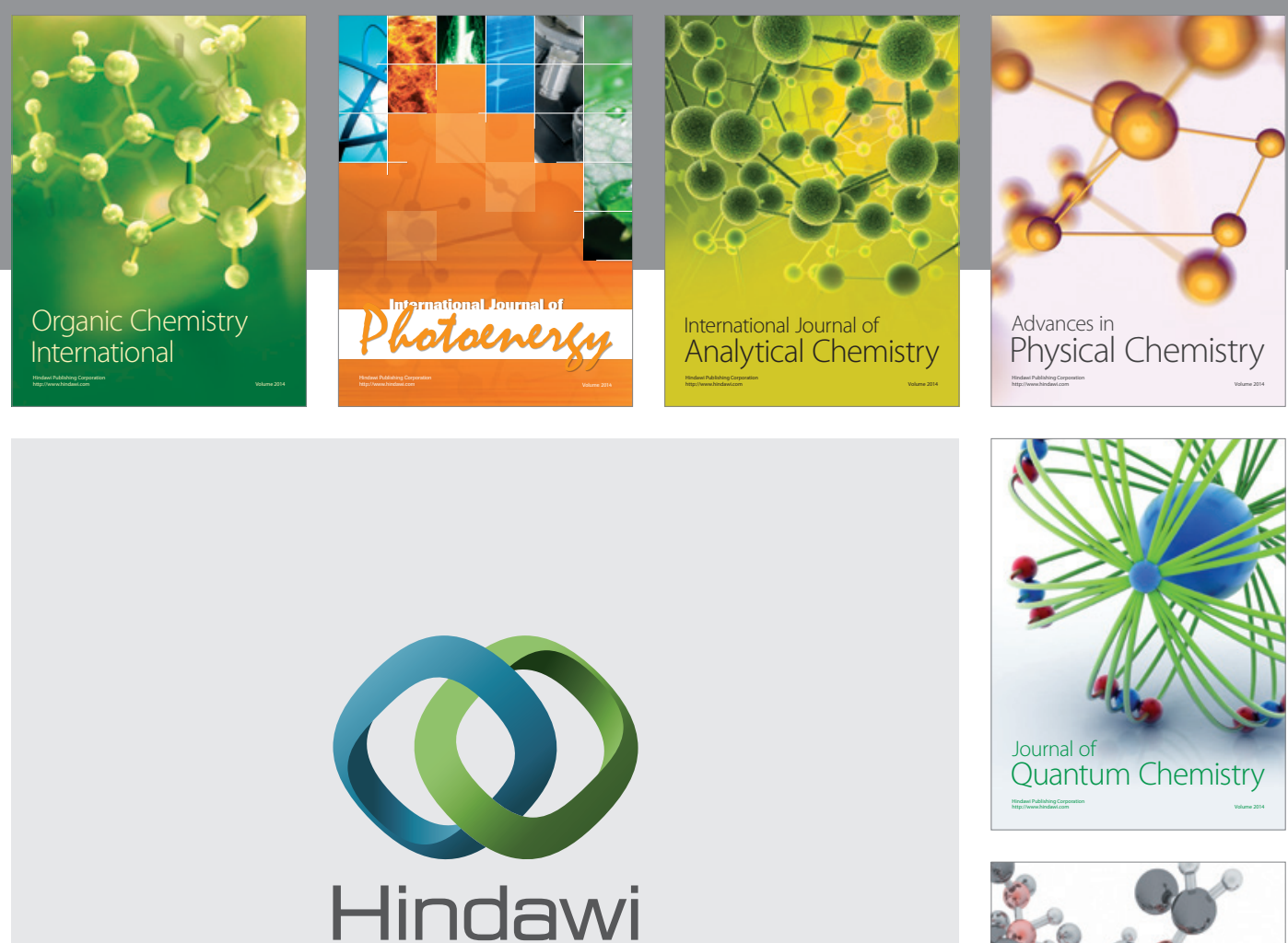

Submit your manuscripts at

http://www.hindawi.com

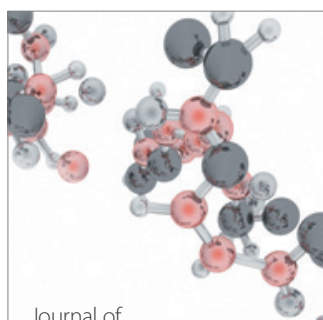

Analytical Methods

in Chemistry

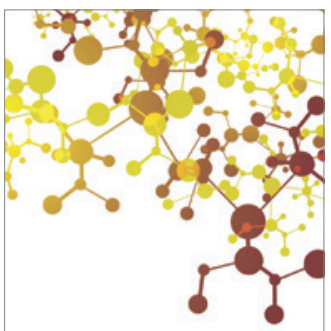

Journal of

Applied Chemistry

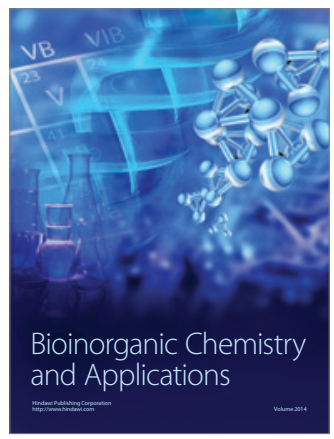

Inorganic Chemistry
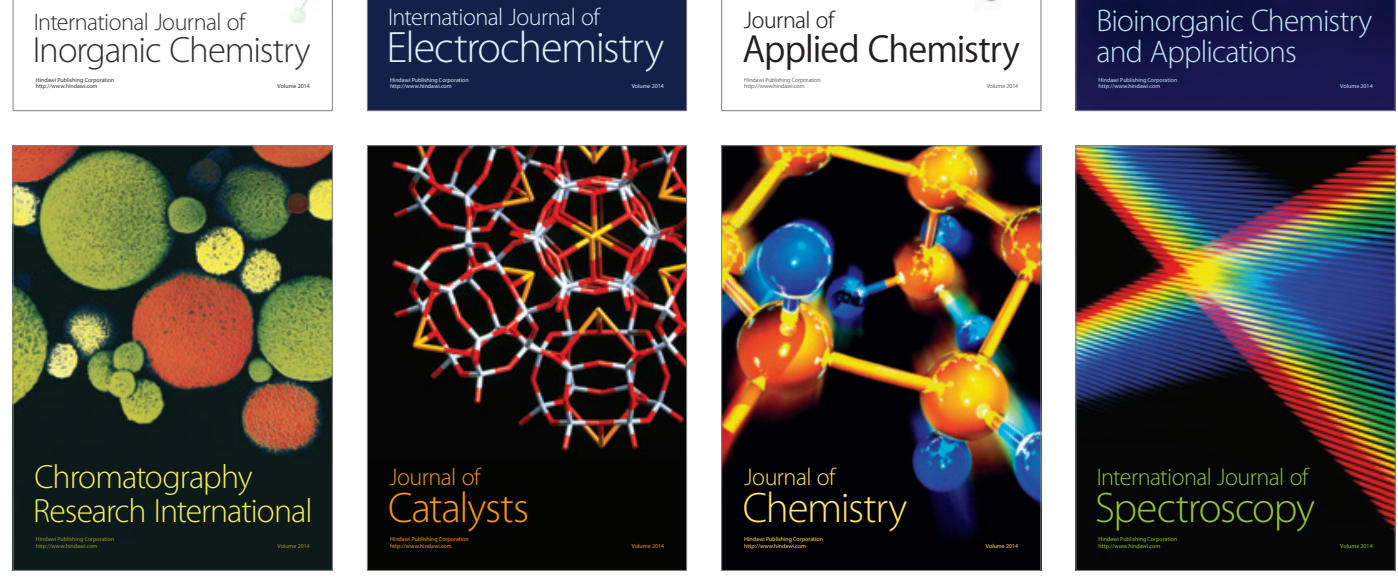